\title{
Desemprego tecnológico: Ricardo, Marx e o caso da indústria de transformação brasileira (1990-2007) ${ }^{1}$
}

\author{
Joaquim Miguel Couto ${ }^{2}$ \\ Maria de Fátima Garcia ${ }^{3}$ \\ Carlos Eduardo de Freitas ${ }^{4}$ \\ Rodolfo Cezar Silvestre ${ }^{5}$
}

\section{Resumo}

A questão do desemprego tecnológico preocupou a mente de dois dos maiores pensadores da ciência econômica: David Ricardo e Karl Marx. Ambos acreditaram que a introdução de novas máquinas poderia causar uma situação de desemprego crônico durante certo período de tempo. No entanto, esta era apenas uma possibilidade, que já havia ocorrido no capitalismo industrial inglês, mas que poderia ser evitada caso novos investimentos absorvessem a mão de obra dispensada pela introdução de nova maquinaria. O Brasil, por sua vez, passou, ao longo da década de 1990, por um período de reestruturação de seu parque industrial que, mediante a metodologia utilizada em nosso estudo, resultou na conclusão da existência do fenômeno do desemprego tecnológico durante boa parte da referida década.

Palavras-chave: Desemprego tecnológico; Ricardo; Marx; Indústria de transformação.

\begin{abstract}
Technological unemployment: Ricardo, Marx, and the case of the manufacturing industry in Brazil (1990-2007)

The issue of technological unemployment was a cause for concern for two of the greatest thinkers in the field of economic science: David Ricardo and Karl Marx. Both believed that the introduction of new machines could bring about chronic unemployment for a certain period of time. However, this was only a possibility that had already taken place within English industrial capitalism, but that could be avoid if new investments absorbed the workforce laid off by the introduction of new machinery. In the case of Brazil, the country underwent a restructuring period of its industrial base during the 1990s, which according to the methodology employed in our study, verified the existence of the technological unemployment phenomenon during much of the aforementioned decade.
\end{abstract}

Keywords: Technological unemployment; Ricardo; Marx; Manufacturing industry.

JEL J34, L23, O14, B31.

(1) Trabalho recebido em 17 de outubro de 2008 e aprovado em 11 de março de 2010.

(2) Professor do Departamento de Economia da Universidade Estadual de Maringá (UEM), Maringá, PR, Brasil. E-mail: jmcouto@uem.br.

(3) Professora do Departamento de Economia da Universidade Estadual de Maringá (UEM), Maringá, PR, Brasil. E-mail: mfgarcia@uem.br.

(4) Professor da Universidade Federal de Mato Grosso (UFMT/CUR/CE), Cuiabá, MT, Brasil. E-mail: cefreitas@ufmt.br.

(5) Bacharel em Ciências Econômicas pela Universidade Estadual de Maringá (UEM), Maringá, PR, Brasil. E-mail: rodolphuscaesar@gmail.com.

Economia e Sociedade, Campinas, v. 20, n. 2 (42), p. 299-327, ago. 2011. 


\section{Introdução}

Grandes escritores ao longo dos séculos, principalmente de ficção científica, imaginaram um mundo em que as máquinas iriam substituir os trabalhadores no árduo esforço de produzir bens e serviços. Livres das obrigações produtivas, ou da maior parte delas, os homens teriam mais tempo para dedicar sua força e inteligência a atividades mais prazerosas, tornando a vida humana mais alegre e menos sofrida. Até mesmo Aristóteles, um dos maiores pensadores da humanidade, imaginou uma sociedade sem a necessidade de trabalho e, por consequência, sem a necessidade de escravos ${ }^{6}$. Keynes (1999) chegou a imaginar o homem trabalhando apenas três horas por dia no ano de 2030.

No entanto, desde o século XVIII, os trabalhadores sentiram que o progresso do uso das máquinas não estava trazendo tanta felicidade assim. Demitidos pela introdução de máquinas modernas, os operários sem salários viraram mendigos nas grandes cidades europeias. O problema era o sistema econômico em que a nova maquinaria, poupadora de mão de obra, estava sendo inserida: o sistema capitalista. Neste sistema, o trabalhador trocado pela máquina não poderia dedicar o seu novo tempo livre às atividades prazerosas da vida, pois, sem o trabalho, os operários ficavam sem uma renda para comprar os meios necessários a sua subsistência e de sua família. O movimento luddita foi a consequência do mal que a maquinaria causou a grande número de trabalhadores ingleses na década de 1810 .

Dois dos maiores economistas que já existiram, David Ricardo e Karl Marx, enxergaram o problema do desemprego tecnológico, mas entenderam que existia solução para o mesmo dentro do próprio sistema capitalista. Por outro lado, a revolução tecnológica da microeletrônica da década de 1970, e que chegou ao sistema produtivo do Brasil na década de 1990, trouxe o problema do desemprego para uma grande parcela dos trabalhadores da indústria de transformação brasileira. Estaríamos vivenciando o fenômeno do desemprego tecnológico em nosso país?

O objetivo deste artigo é responder esta pergunta. Para cumprir tal objetivo, dividimos o texto em três partes. Na primeira, trataremos do pensamento de David Ricardo sobre a maquinaria e sua relação com a classe trabalhadora. $\mathrm{Na}$ segunda parte, analisaremos as ideias de Karl Marx sobre o desemprego tecnológico expostas, principalmente, no capítulo XIII de $O$ capital. A terceira parte, mais extensa, estudará a reestruturação produtiva ocorrida na indústria de

(6) "Se cada ferramenta, obedecendo às ordens ou mesmo pressentindo-as, pudesse realizar a obra que lhe coubesse, como os engenhos de Dédalo que se movimentavam por si mesmos, ou as trípodes de Hefaísto que iam por si mesmas ao trabalho sagrado, se as lançadeiras tecessem por si mesmas, não seriam, então, necessários auxiliares para o mestre-artesão nem escravos para o senhor" (Aristóteles apud Marx, 1984, p. 32). 
transformação brasileira (1990-2007) e suas consequências sobre o volume de emprego, procurando explicitar a existência ou não do desemprego tecnológico.

No entanto, antes de iniciar os capítulos, temos que responder uma outra pergunta: o que é desemprego tecnológico? Seria a existência de operários demitidos por causa de uma nova máquina que foi introduzida na esfera produtiva de uma ou algumas empresas? Nada disso. A demissão não caracteriza a existência do desemprego tecnológico. A resposta mais correta é a seguinte: existe desemprego tecnológico quando o operário demitido pela introdução de uma nova máquina (ou tecnologia) no processo produtivo não encontra um novo trabalho num curto período de tempo. Caso o trabalhador demitido pela nova máquina encontre um novo emprego rapidamente numa outra empresa, ele não é um desempregado, logo não existe desemprego tecnológico porque não existe desemprego. O desemprego tecnológico só existe quando há desemprego e caso este desemprego tenha sido causado pela introdução de uma nova máquina ou tecnologia ${ }^{7}$.

\section{0 desemprego tecnológico em Ricardo ${ }^{8}$}

O desenvolvimento do capitalismo industrial na Europa não foi um mar de rosas. A indústria manufatureira encontrou, desde cedo, um problema que perturbaria seus objetivos mercantis: a revolta dos trabalhadores contra a introdução de máquinas modernas que, se por um lado, poupavam trabalho, por outro, levavam centenas de trabalhadores ao desemprego numa única fábrica. Hobsbawn (1981) descreveu reações agressivas dos operários contra as novas máquinas em vários países da Europa (Inglaterra, Alemanha, França, Bélgica e Itália) nos anos de 1718, 1724, 1726, 1728, 1740, 1765 e 1802. Três máquinas impulsionaram as revoltas dos trabalhadores: a máquina de fiar automática (1764), a máquina de fiar hidráulica (1769) e a máquina híbrida (1779). Dennis (1978) e Smiles (2004) relataram a destruição de várias fábricas na Inglaterra, no ano de 1779, nos condados de Lancaster, Hargreaves, Arkwright e Kay. Por essa época surgiu o lendário Ned Ludd que, por algum motivo desconhecido, invadiu uma

(7) Numa conferência ministrada na Universidade de Madri, em junho de 1930, o eminente economista John Maynard Keynes definiu de maneira semelhante o conceito de desemprego tecnológico: "(..) somos atingidos por uma nova doença da qual alguns leitores podem ainda desconhecer o nome, mas da qual muito se irá falar nos próximos anos: o desemprego tecnológico. Isso significa que o desemprego resultante da descoberta de instrumentos que economizem mão de obra caminha mais rapidamente do que nossa capacidade de encontrar novos empregos para a mesma mão de obra" (Keynes, 1999, p. 95).

(8) David Ricardo nasceu em Londres no dia 18 de abril de 1772. Aprendeu com o pai o jogo do mercado de ações inglês, tornando-se rapidamente um homem rico. Ao publicar seu Ensaio sobre a Lei dos Cereais, em fevereiro de 1815, Ricardo obteve o respeito de James Mill, Jeremy Bentham e Jean-Babtiste Say. Malthus já era seu amigo. Por influência de James Mill, publicou em 1817 seu grande livro, intitulado "Princípios de economia política e tributação". Em 1819, foi eleito para a Câmara dos Comuns, fazendo-se ouvir por toda a Inglaterra. Morreu no dia 11 de setembro de 1823, aos 51 anos de idade. 
fábrica e quebrou uma máquina de tricotear meias no condado inglês de Leicestershire. No entanto, nos locais onde as novas máquinas não causaram desemprego, não houve hostilidades contra as mesmas (Hobsbawn, 1981).

Apesar dessas revoltas do século XVIII, nenhuma alcançou a amplitude do movimento popular iniciado na Inglaterra em 1811, na região de Nottingamshire. Teares e máquinas tricotadeiras movidas a vapor despejaram nas ruas milhares de operários. A reação dos operários foi violenta: hordas organizadas de centenas de trabalhadores desempregados e mascarados invadiam as fábricas durante a noite $\mathrm{e}$, armados de martelos, lanças e pistolas, quebravam todas as máquinas que encontravam pela frente. Logo o problema se espalhou para Yorkshire, Leicestershire, Derbyshire e Lancashire. Em março de 1812, um sujeito de codinome "General Ludd" escreveu uma carta ameaçando quebrar os teares mecânicos de um industrial de Huddersfield. A partir de então, as revoltas populares receberam o nome de "movimento luddita". Nunca se descobriu a verdadeira identidade desse primeiro "General" (Schilling, 2008).

À medida que o movimento crescia, novos líderes iam surgindo para comandar milhares de homens, cada um assumindo o codinome de "General Ludd". Dependendo do condado, o número variava de três a oito mil ludditas. Diante do tumulto social, em 1812, o Parlamento inglês aprovou a Frame Braking $A c t$, lei que permitia a condenação à morte das pessoas envolvidas nas quebras das máquinas (Thompson, 1987).

O grande momento do movimento luddita ocorreu no condado de York, em abril de 1812. Dezenas de trabalhadores desempregados invadiram e destruíram a fábrica de William Cartwright. As investigações policiais levaram 64 trabalhadores ao tribunal no ano seguinte: 13 foram condenados à morte (Ibid).

O movimento luddita arrefeceu-se nos anos seguintes, mas não deixou de existir. A data que marcou o encerramento do movimento foi trágica. No dia 16 de agosto de 1819, uma grande multidão, estimada entre 60 a 80 mil pessoas, compareceu ao parque de Saint-Peter's Field, Manchester (a maior cidade industrial da Inglaterra na época), para reivindicar melhores condições de trabalho ${ }^{9}$. Durante a manifestação, a cavalaria do exército inglês disparou em direção à multidão, ocasionando 15 mortes e centenas de feridos. $\mathrm{O}$ massacre de Peterloo, como ficou conhecido o acontecimento, gerou protestos em toda a GrãBretanha e marcou o fim do movimento luddita.

(9) Em 1817, a jornada de trabalho nas fábricas inglesas começava, em média, às cinco horas da manhã e terminava às sete horas da noite, com intervalos de meia hora para as refeições (Barnes, 1955). 
Mesmo com toda a repercussão do movimento operário, a nova ciência da Economia Política não prestou atenção imediata aos fatos que estavam ocorrendo na sociedade inglesa. Somente em fevereiro de 1815, ainda como um jovem iniciante nos segredos da Economia Política, David Ricardo escreveu algo sobre o que ocorria. Em rápida passagem de seu "Ensaio sobre a influência do baixo preço do trigo sobre os lucros do capital, mostrando a inconveniência de restrições à importação", Ricardo afirmava apenas que a "maquinaria aperfeiçoada" tendia a elevar os "salários reais do trabalho", sendo, portanto, positiva para a classe trabalhadora. Nada registrou sobre o efeito da "maquinaria aperfeiçoada" em relação à demanda por trabalho (Ricardo, 1965) ${ }^{10}$.

A discussão esquenta em 1817, quando o eminente engenheiro inglês John Barton passa a defender a ideia de que a introdução de maquinaria moderna era maléfica à classe trabalhadora, em razão do desemprego resultante. Ricardo, ciente das ideias de Barton, escreveu-lhe uma carta, em 20 de maio de 1817, contestando suas opiniões. Entretanto, na primeira edição de seus "Princípios de economia política e tributação", de abril de 1817, Ricardo não fez nenhuma referência a este assunto.

Talvez motivado pela missiva de Ricardo, Barton publicou um folheto intitulado "Observações sobre as condições das classes trabalhadoras", ainda em 1817. Seu folheto dizia que o emprego da maquinaria era fator de redução da demanda por trabalho, causando desemprego:

À medida que as técnicas se desenvolvem e a civilização se generaliza, o capital fixo [máquinas] é cada vez maior em relação ao capital circulante [trabalho]. O montante de capital fixo empregado na produção de uma peça de musselina inglesa é pelo menos cem ou mesmo mil vezes maior do que o empregado na produção de uma peça similar de musselina na Índia. E a proporção de capital circulante empregado é mil vezes menor. É fácil perceber que, sob determinadas circunstâncias, se pode agregar ao capital fixo a totalidade da poupança anual de um povo trabalhador, o que não produziria nenhum efeito para aumentar a demanda de trabalhadores (Barton apud Ricardo, 1982, p. 266).

O folheto de Barton não influenciou as ideias de Ricardo sobre os efeitos da maquinaria e nem mesmo o motivou a escrever sobre ela na segunda edição dos seus "Princípios", de fevereiro de 1819. Já num discurso proferido no Parlamento inglês, em 16 de dezembro de 1819, na condição de deputado eleito, Ricardo declarou que "(...) não pode ser negado que, considerando a questão em seu conjunto, a maquinaria não reduz a demanda por trabalho" e que, portanto, não pode ser considerada desfavorável à classe trabalhadora (Ricardo apud Sraffa, 1982, p. 31).

(10) Os próximos nove parágrafos estão, em parte, baseados em Sraffa (1982). 
Em janeiro de 1820, John Ramsay McCulloch, pertencente ao círculo de amigos de Ricardo, publicou um artigo na Edimburg Review no qual fazia uma resenha do folheto de Barton de 1817. Intitulado "Impostos e as leis dos cereais", o artigo de $\mathrm{McCulloch}$ concordava com Barton sobre os malefícios da máquina ao trabalhador. Em suas palavras, McCulloch afirmava que “(...) o capital fixo investido numa máquina deve sempre deslocar uma quantidade consideravelmente maior de capital circulante, pois caso contrário não haveria motivo para aumentálo, uma vez que o seu primeiro efeito é baixar e não aumentar a taxa de salários" (McCulloch apud Sraffa, 1982, p. 31-32). Ao concluir que o investimento em capital fixo (máquinas) deslocava capital circulante (trabalho), McCulloch estava dizendo que uma nova máquina sempre reduz a quantidade de trabalho necessário à produção e acabava por diminuir os salários do trabalhador, haja vista o aumento da oferta de mão de obra.

Desta vez, Ricardo não ficou em silêncio. Escreveu a McCulloch, em março de 1820, contestando sua opinião. Dizia Ricardo “(...) que o emprego da maquinaria nunca reduz a demanda de trabalho (...) nunca é a causa de uma queda do preço do trabalho, mas o efeito de sua elevação" (Ricardo apud Sraffa, 1982, p. 32). Ricardo conseguiu convencer McCulloch: a maquinaria não causava redução na demanda de trabalho. Em novo artigo publicado no Edimburg Review, em março de 1821, McCulloch expunha sua nova posição, dizendo que "(...) nenhum aperfeiçoamento da maquinaria pode diminuir a demanda de trabalho, ou reduzir a taxa de salários" (McCulloch apud Sraffa, 1982, p. 32).

Portanto, entre 1815 e março de 1820, Ricardo não admitia que a introdução de novas máquinas pudesse causar uma redução no volume de emprego. Suas ideias começaram a mudar, porém, depois da publicação dos Princípios de Malthus (de 19 de abril de 1820). Por sugestão de McCulloch, Ricardo passou os meses de abril a novembro de 1820 escrevendo críticas sobre o livro de Malthus. As Notas sobre o livro de Malthus só seriam publicadas em 1928.

As Notas de Ricardo em que aparece a mudança de seu pensamento em relação à maquinaria e seu efeito sobre a classe trabalhadora são as de números 149 e 153. Na Nota 149, diz que a demanda efetiva de trabalho depende exclusivamente do aumento daquela parcela do capital circulante que paga os salários. Em geral, o capital investido na produção é uma combinação de capital fixo e capital circulante. Se os lucros continuarem os mesmos, o capitalista é indiferente sobre a proporção em que o capital se dividirá entre fixo ou circulante. Porém, essa escolha tem grande importância para aqueles que vivem dos salários do trabalho. Assim, se o capital for aplicado numa proporção maior na aquisição 
de máquinas, existirá uma menor demanda por trabalho (Ricardo, 1983). Já na Nota 153, Ricardo aproximava-se ainda mais das ideias de Barton:

É possível que quase todo o trabalho executado pelo homem seja realizado por cavalos; nesse caso, a substituição por cavalos, mesmo acompanhada por uma produção maior, seria vantajosa para as classes trabalhadoras, ou, ao contrário, diminuiria substancialmente a demanda por trabalho? Limito-me a dizer o seguinte: pode acontecer que, com uma forma de cultivo mais barata, a demanda de trabalho possa diminuir; e, com uma forma de cultivo mais cara, a demanda de trabalho possa aumentar (Ricardo, 1983, p. 145-146).

Em suma, tanto a maquinaria quanto os cavalos poderiam diminuir a demanda por trabalho. No início de 1821, Malthus já sabia da mudança de opinião de Ricardo sobre os efeitos da maquinaria aperfeiçoada na demanda por trabalho. Numa carta endereçada a Sismondi, de 12 de março de 1821, Malthus assinalava essa mudança. McCulloch, porém, continuava sem saber de nada, publicando seu folheto naquele mesmo mês de março.

McCulloch só foi informado da mudança de opinião de Ricardo através de uma carta datada de 25 de abril de 1821. Nesta, Ricardo anunciava sua mudança de opinião "(...) em relação às vantagens da maquinaria" (Ricardo apud Sraffa, 1982, p. 33). Somente com a publicação da terceira edição dos Princípios de Ricardo, em maio de 1821, McCulloch conheceu as razões que motivaram Ricardo a mudar de ideia. Na nova edição, Ricardo não fazia nenhuma referência ao primeiro folheto de McCulloch (de janeiro de 1820), que concordava com as ideias de Barton. Finalmente, em 5 de junho de 1821, McCulloch escreveu a Ricardo contestando sua nova opinião e o "(...) enorme equívoco nos princípios que sem cautela você endossou com seu nome" (McCulloch apud Sraffa, 1982, p. 32). Finaliza a carta dizendo que se essa fosse a verdade sobre a maquinaria e seus efeitos sobre a classe trabalhadora "(...) as leis contra os Ludditas são uma vergonha para o Código [inglês]" (Ibid). A resposta de Ricardo veio numa carta de 18 de junho de 1821, mostrando pouca modéstia e certa arrogância: "Essas verdades [como a introdução das máquinas reduziria a demanda por trabalho] me parecem tão facilmente demonstráveis como qualquer das correspondentes à geometria, e me surpreende não tê-las encontrado antes" (Ricardo apud Sraffa, 1982, p. 33).

A terceira e derradeira edição dos Princípios de Ricardo é um livro bem diferente das edições anteriores. Trazia um novo capítulo, intitulado "Sobre a maquinaria" (capítulo XXXI), considerado por Sraffa (1982, p. 31) como "a modificação mais revolucionária na terceira edição (...) na qual Ricardo abandona sua opinião anterior de que a introdução da maquinaria é benéfica a todas as 
diferentes classes da sociedade". No início deste novo capítulo, Ricardo comentou a mudança de seu pensamento:

No presente capítulo investigarei um pouco a influência da maquinaria sobre os interesses das diferentes classes da sociedade, uma questão de grande importância e uma das que parece nunca ter sido estudada de maneira a conduzir a quaisquer resultados certos e satisfatórios. Para mim é muito importante manifestar minha opinião a respeito desta questão porque, depois de uma maior reflexão, ela sofreu uma alteração considerável. E, embora eu acredite não ter publicado nada sobre a maquinaria de que necessite me retratar, já dei meu apoio, por outras formas, a concepções que agora penso serem errôneas. Portanto, torna-se para mim um dever submeter a exame minhas concepções atuais, assim como as razões pelas quais as sustento (Ricardo, 1982, p. 261).

Explica Ricardo que, de início, julgava que a introdução da maquinaria era benéfica aos capitalistas, proprietários de terras e trabalhadores, pois acarretava uma diminuição nos preços das mercadorias. Não ocorreria redução de salários e os trabalhadores despedidos de uma indústria poderiam encontrar trabalho noutra empresa, pois “(...) o capital que os empregava não havia deixado de existir, e como seria do interesse de seus possuidores empregá-lo produtivamente, pareciame que ele seria empregado na produção de alguma outra mercadoria, útil à sociedade em relação à qual não poderia deixar de haver uma demanda" (Ibid, p. 261-262). Ou seja, Ricardo acreditava que um trabalhador demitido de determinada empresa iria arrumar emprego rapidamente em outra atividade necessária à sociedade.

Esta era sua antiga opinião. Dizia, agora, que estava “(...) convencido de que a substituição de trabalho humano por maquinaria é frequentemente muito prejudicial aos interesses da classe dos trabalhadores" (Ibid, p. 262). Ricardo explica sua mudança de opinião através dos conceitos de rendimento bruto e rendimento líquido. Não é necessário entrar nessa discussão. O que interessa é sua conclusão de que “(...) a mesma causa que pode aumentar o rendimento líquido do país, pode ao mesmo tempo tornar a população excedente e deteriorar as condições de vida dos trabalhadores" (Ibid, p. 262). Ou seja, a maquinaria aperfeiçoada pode ao mesmo tempo aumentar a produção do país e diminuir a quantidade de trabalho utilizada na mesma. Na página seguinte, Ricardo reafirma o infortúnio da classe trabalhadora: “(...) ocorrerá necessariamente uma redução da demanda de trabalhadores; uma parte da população tornar-se-á excessiva e a situação da classe trabalhadora será de grande sofrimento e pobreza" (Ibid, p. 263).

Para Ricardo, a nova maquinaria causaria desemprego tanto na produção agrícola quanto na produção manufatureira. E mais, ao diminuir a demanda por trabalhadores, também se reduziria, em parte, a produção de mercadorias 
consumidas pelos trabalhadores, ocasionando uma nova redução na demanda por trabalho. Apoiado nessas observações, Ricardo concluiu que a "(...) opinião defendida pela classe trabalhadora de que o emprego da maquinaria é frequentemente prejudicial aos seus interesses não emana de preconceitos ou erros, mas está de acordo com os princípios corretos da Economia Política" (Ibid, p. 264).

Diz ainda que "As máquinas e o trabalhador mantêm-se em constante competição, e as primeiras só podem ser utilizadas se o preço do trabalhador se elevar" (Ibid, p. 266). Assim, o capitalista só iria introduzir uma máquina moderna quando os salários subissem a determinado nível que compensasse o investimento numa máquina que poupasse trabalho. Se os salários fossem baixos, não haveria incentivo para investir em maquinaria. Como exemplo, cita os Estados Unidos que produziam alimentos facilmente e os salários eram baixos, não existindo uma "tentação tão grande ao uso de maquinaria como na Inglaterra, onde a alimentação é cara" (Ibid, p. 266) e os salários são altos.

Apesar dessas conclusões, Ricardo entendia que novos investimentos em capital fixo poderiam aumentar a demanda de trabalhadores, mas não na mesma magnitude anterior à introdução da maquinaria (Ibid, p. 266). Ou seja, um novo investimento numa máquina aperfeiçoada gerava demanda de trabalhadores, mas numa proporção menor quando comparada à antiga maquinaria. Nesse trecho, Ricardo cita o folheto de Barton de 1817, afirmando que "Sua obra contém muitas informações valiosas" (Ibid, p. 266). Embora mal explicada, essa passagem da obra de Ricardo indicava que novos investimentos (por exemplo, numa nova fábrica) poderiam empregar os trabalhadores demitidos pela introdução da nova maquinaria (na antiga fábrica), evitando o fenômeno do desemprego tecnológico.

Por fim, apesar de reconhecer que a maquinaria poderia causar desemprego, Ricardo ponderava que não se deveria deixar de encorajar a utilização da maquinaria. Era preferível gerar pouco emprego no país, devido à máquina aperfeiçoada, do que exportar esse capital para outra nação:

A utilização de maquinaria num país nunca deveria deixar de ser incentivada, pois, se não for permitido ao capital obter o maior rendimento líquido que o emprego de máquinas possibilita, ele será transferido para o exterior e isso representará um desestímulo muito maior à demanda de trabalho do que a generalização mais completa do uso de máquinas, uma vez que, enquanto o capital é aplicado no país, alguma demanda de trabalho deverá ser criada; as máquinas não funcionam sem a intervenção do homem, e também não podem ser construídas sem a contribuição do seu trabalho. Investindo uma parte do capital em maquinaria aperfeiçoada haverá uma redução na progressiva demanda de trabalho; exportando-o para outro país, a demanda será totalmente eliminada (Ibid, p. 266-267). 
Assim, Ricardo chegou à conclusão de que a introdução de nova maquinaria poderia causar a dispensa de trabalhadores, e que estes poderiam ficar algum tempo desempregados, sofrendo enormemente com isso. Teríamos o que chamamos hoje de "desemprego tecnológico ou estrutural". Mas esta era apenas uma possibilidade. Novos investimentos em novas fábricas poderiam evitar que o operário dispensado ficasse muito tempo sem trabalho. Schumpeter (1958, p. 49) conseguiu entender o que Ricardo escreveu: “(...) estava provando somente uma possibilidade" ${ }^{\prime 1}$. Possibilidade bem real dado o movimento luddita $\mathrm{e}$ as consequências adversas aos trabalhadores dispensados naquele início do século XIX.

Desta forma, podemos retirar três conclusões do estudo de Ricardo: 1) a introdução de nova maquinaria reduzia a quantidade de mão de obra necessária à produção, podendo gerar o fenômeno do desemprego tecnológico; 2) dependendo do volume de novos investimentos, os demitidos pela introdução da maquinaria poderiam encontrar emprego em outras empresas, não ocorrendo desemprego; 3) a introdução de nova maquinaria nunca deveria deixar de ser incentivada ou proibida, pois o capitalista poderia transferir seus investimentos para outra nação, não gerando nenhum trabalho no país que proibiu seu emprego.

\section{$2 O$ desemprego tecnológico em Marx ${ }^{12}$}

Karl Marx publicou o primeiro livro de $O$ capital (1867) quase cinquenta anos após a terceira edição dos Princípios de Ricardo. A questão do desemprego provocado pela introdução da maquinaria está fartamente documentada no capítulo XIII, intitulado "Maquinaria e a Grande Indústria". Marx estudou minuciosamente seus antecessores da Economia Política e sabia das mudanças de opinião de Ricardo sobre a maquinaria e seu prejuízo à classe trabalhadora:

(11) A passagem integral de Schumpeter (1958, p. 49) sobre o capítulo XXXI de Ricardo é a seguinte: "A princípio, Ricardo sentiu-se inclinado a compartilhar do ponto de vista, muito comum em todos os tempos, de que a introdução de máquinas, no processo de produção, dificilmente poderia deixar de beneficiar as massas. Quando começou a duvidar dessa opinião ou, em todo o caso, de sua validez geral, com franqueza característica, reviu a posição. Assim fazendo, também caracteristicamente, recuou e, utilizando seu método habitual de 'imaginar casos convincentes', elaborou um exemplo numérico, bem conhecido de todos os economistas, para demonstrar que as coisas poderiam pender para o outro lado. Por um lado, não tentou negar que estava provando somente uma possibilidade - embora não improvável - ou, por outro lado, que, no final, o trabalho seria beneficiado como resultado da mecanização, através de seus efeitos posteriores no rendimento total, preços, etc.".

(12) Karl Heinrich Marx nasceu em Trier, Prússia (atual Alemanha), em 5 de maio de 1818. Estudou Direito nas universidades de Bonn e Berlim, doutorando-se em Filosofia pela Universidade de Iena, em 1841. O Manifesto do Partido Comunista, escrito por Marx e Engels, e publicado em fevereiro de 1848, tornar-se-ia um dos principais textos políticos da história das ideias. Exilado em Londres, a partir de 1848, voltou toda sua atenção ao estudo da economia política, publicando, em 1867, o primeiro volume de $O$ capital: crítica da economia política. Faleceu em 14 de março de 1883, aos 64 anos de idade. 
"Ricardo de início compartilhava desse ponto de vista, mas retratou-se mais tarde com sua característica imparcialidade científica e amor à verdade" (Marx, 1984, p. 54). O economista alemão, desde o início, admitiu que a maquinaria poupava trabalho e era, assim, prejudicial à classe trabalhadora. No entanto, tinha a ideia de que a maquinaria não era em si culpada pela desgraça dos trabalhadores, mas sim o seu aproveitamento pelo sistema capitalista.

O primeiro ponto sobre a maquinaria destacado por Marx é que esta eliminou a necessidade da força muscular no processo produtivo. Qualquer trabalhador poderia operar uma máquina, independente de sua força física. Isso permitiu que mulheres e crianças fossem recrutadas para o trabalho fabril. A inclusão de mulheres e crianças aumentou a oferta de trabalho, ocasionando uma redução dos salários. Dessa forma, para sustentar sua família, o trabalhador era quase que "obrigado" a empregar sua mulher e seus filhos ${ }^{13}$.

Pressionado pela classe trabalhadora, o parlamento inglês limitou a jornada de trabalho a 12 horas diárias, em 1832. Já em 1847, foi estabelecida a jornada de 10 horas diárias nas fábricas de algodão, lã, seda e linho. Baseando-se em vários relatórios de inspeção de fábricas inglesas, Marx constatou que a contínua redução da jornada de trabalho impulsionou o aperfeiçoamento da maquinaria (Ibid, p. 34-38).

Demonstra, com base em dados de meados do século XIX, que, com a utilização de modernas máquinas, a produção aumentou enquanto se reduziu o número de trabalhadores. E mais, dado que a maquinaria intensificou o trabalho fabril, a jornada de trabalho de 10 horas estava produzindo uma quantidade maior de produtos do que a antiga jornada de trabalho de 12 horas (Ibid, p. 38-39). Desta maneira, Marx reconheceu que a "maquinaria é o meio mais poderoso de elevar a produtividade do trabalho" (Ibid, p. 28).

Afirma que, somente com a introdução da maquinaria, o trabalhador revoltou-se contra o próprio meio de produção ${ }^{14}$. Durante o século XVII, muitos países da Europa vivenciaram "revoltas de trabalhadores" contra a maquinaria (neste caso, o tear de fitas). A revolta contra esse tipo de máquina, que desempregava os trabalhadores, levou à proibição de seu uso em várias cidades

(13) "A maquinaria, ao lançar todos os membros da família do trabalhador no mercado de trabalho, reparte o valor da força de trabalho do homem por toda sua família. Ela desvaloriza, portanto, sua força de trabalho (...) O trabalhador vendia anteriormente sua própria força de trabalho, da qual dispunha como pessoa formalmente livre. Agora vende mulher e filho. Torna-se mercador de escravos" (Marx, 1984, p. 23).

(14) "Mas só a partir da introdução da maquinaria é que o trabalhador combate o próprio meio de trabalho, e a forma de existência material do capital. Revolta-se contra essa forma determinada do meio de produção como base material do modo capitalista de produção" (Ibid, p. 46) 
europeias (Veneza, no início do século XVII; Leyden, em 1623/1639; Colônia, em 1676; e em toda a Alemanha, em 1685). Na Inglaterra, no início do século XIX, o emprego do tear a vapor levou ao conhecido movimento luddita ${ }^{15}$. No entanto, Marx deixava claro que a revolta do trabalhador contra a máquina era errada. Sua revolta deveria ser dirigida ao modo de produção capitalista e não à máquina, que poupava e facilitava o trabalho do ser humano, sendo "uma vitória do homem sobre a força da natureza" (Ibid, p. 56).

Marx entende que a indústria permitiu a ocupação da população que foi expulsa do campo. Esse era o lado positivo. Mas com a introdução da maquinaria, veio o seu lado negativo:

A parte da classe trabalhadora que a maquinaria transforma em população supérflua, isto é, não mais imediatamente necessária para a autovalorização do capital, sucumbe, por um lado, na luta desigual da velha empresa artesanal e manufatureira contra a mecanizada, inunda, por outro lado, todos os ramos mais acessíveis da indústria, abarrota o mercado de trabalho e reduz, por isso, o preço da força de trabalho abaixo de seu valor. Para os trabalhadores pauperizados, deve ser grande consolo acreditar, por um lado, que seu sofrimento seja apenas 'temporário', por outro, que a maquinaria só se apodere paulatinamente de todo um setor de produção, ficando reduzida a dimensão e a intensidade de seu efeito destruidor. Um consolo bate o outro. Onde a máquina se apodera paulatinamente de um setor da produção, produz miséria crônica nas camadas de trabalhadores que concorrem com ela. Onde a transição é rápida, seus efeitos são maciços e agudos. A história mundial não oferece nenhum espetáculo mais horrendo do que a progressiva extinção dos tecelões manuais de algodão ingleses, arrastando-se por décadas e consumando-se finalmente em 1838 (Ibid, p. 48-49).

O autor não concorda que o sofrimento dos trabalhadores provocado pela maquinaria seja "temporário". Para ele, "o efeito 'temporário' da maquinaria é permanente, ao se apoderar constantemente de novos setores da produção" (Ibid, p. 49). Em suas palavras, "O meio de trabalho mata o trabalhador" (Ibid, p. 49).

Em seguida, critica a "teoria da compensação" desenvolvida por economistas ingleses do início do século $\mathrm{XIX}^{16}$. Tal teoria dizia que embora a maquinaria deslocasse trabalhadores, estes eram novamente empregados pelo mesmo capital, que seria poupado pela introdução da maquinaria. Marx não concorda com essa liberação de capital para contratar os trabalhadores desempregados. Diz que não há uma liberação de capital, mas sim uma transformação do capital variável (mão de obra) em capital constante (máquina). A

(15) "A destruição maciça de máquinas nos distritos manufatureiros ingleses durante os 15 primeiros anos do século XIX, provocada sobretudo pelo emprego do tear a vapor, ofereceu, sob o nome de movimento luddita, pretexto ao governo antijacobino de um Sidmouth, Castlereagh, etc., para as mais reacionárias medidas de violência" (Ibid, p. 47).

(16) "Toda uma série de economistas burgueses, como James Mill, McCulloch, Torrens, Senior, J. St. Mill etc., afirma que toda maquinaria que desloca trabalhadores sempre libera, simultânea e necessariamente, capital adequado para empregar esses mesmos trabalhadores" (Ibid, p. 54). 
cada aperfeiçoamento da maquinaria ocupavam-se menos trabalhadores: "Um dos grandes méritos de Ricardo é ter entendido a maquinaria não só como um meio de produção de mercadorias, mas também de redundant population [população excedente]" (Ibid, p. 32).

Quanto à criação de novos empregos provocada pela construção da maquinaria, Marx afirma que "na melhor das hipóteses, fabricá-la emprega menos trabalhadores do que sua utilização desloca" (Ibid, p. 55). E mais, o desemprego levava à diminuição no consumo das mercadorias produzidas para atender o consumo dos trabalhadores. Logo, através da "consagrada lei da oferta e da procura", parte dos trabalhadores que produziam mercadorias para trabalhadores também seria demitida.

Marx conclui que "Os fatos verdadeiros, transvestidos pelo otimismo econômico, são estes: os trabalhadores deslocados pela maquinaria são jogados da oficina para o mercado de trabalho, aumentando o número de forças de trabalho já disponíveis para a exploração capitalista” (Ibid, p. 56). Ou seja, aumentando o chamado "exército industrial de reserva".

A maquinaria não causava desemprego apenas na grande indústria, mas também na agricultura. A destruição de máquinas por parte da classe trabalhadora também ocorreu no setor rural: nos anos de 1830/33, trabalhadores agrícolas destruíram máquinas debulhadoras na Inglaterra. Essas quebradeiras ficaram conhecidas como "Rebelião de Swing" porque usavam em suas cartas ameaçadoras o nome fictício de Captain Swing (Ibid, p. 232).

Apesar destas constatações sobre os malefícios da maquinaria, Marx admitiu que o trabalhador demitido pela introdução da maquinaria poderia encontrar uma nova ocupação. Mas isso só ocorreria mediante o investimento de um novo capital, e não pelo mesmo capital que foi empregado na compra da maquinaria, conforme afirmavam os economistas ingleses do início do século $\mathrm{XIX}^{17}$.

Marx entende que a ocupação poderia aumentar com os novos investimentos. Contudo, estes novos investimentos, por conterem maquinaria aperfeiçoada, geravam um menor número de postos de trabalho ${ }^{18}$. Constatou

(17) "Aqui, só isso: os operários postos fora de um ramo da indústria podem, na verdade, procurar emprego em qualquer outro ramo. Se o encontram e, com isso, se recompõe o laço que havia entre eles e os meios de subsistência com eles liberados, então isso acontece por intermédio de novo capital adicional, que procura aplicação; de nenhum modo, porém, por intermédio do capital que já funcionava antes e agora se transformou em maquinaria" (Ibid, p. 56).

(18) "Em termos absolutos, o número de trabalhadores empregados cresceu de 100; em termos relativos, ou seja, em relação ao capital global investido, caiu de 800, pois o capital de 2 mil libras esterlinas teria, no antigo modo de produzir, ocupado 1.200 em vez de 400 trabalhadores. A redução relativa do número de trabalhadores é, portanto, compatível com seu aumento absoluto" (Ibid, p. 62). 
também que o barateamento dos produtos fabricados com novas máquinas permitiria conquistar mercados estrangeiros. Além disso, os trabalhadores excedentes, devido ao emprego da maquinaria, acabavam emigrando para países estrangeiros colonizados. Como exemplo, Marx cita o caso de trabalhadores ingleses que foram trabalhar na Austrália, produzindo lã para a indústria inglesa (Ibid, p. 63).

Outras questões ainda são levantadas. A existência de sobretrabalho (ou hora extra sem remuneração) impedia uma maior contratação de trabalhadores ociosos, reforçando o problema do desemprego. A população, por sua vez, crescia “(.) mais rapidamente do que a necessidade de valorização do capital” (Ibid, p. 209), contribuindo para a existência do exército industrial de reserva.

Podemos concluir, assim, de acordo com as ideias de Marx, que a maquinaria era, em parte, responsável pelo desemprego, mas que novos investimentos poderiam absorver os trabalhadores demitidos. Marx não apontou com clareza, mas demonstrou que sabia que o desemprego dependeria da velocidade de crescimento de quatro variáveis: 1) avanço tecnológico; 2) crescimento populacional; 3) taxa de acumulação de capital (ou novos investimentos); 4) redução da jornada de trabalho.

O avanço tecnológico, representado por novas máquinas, ferramentas e processos de trabalho, diminuía a demanda de trabalhadores. Já o crescimento populacional aumentava a oferta de trabalhadores. Estas duas forças impulsionavam o desemprego. Por outro lado, os novos investimentos e a redução da jornada demandavam mão de obra. Eram duas forças que reduziriam o desemprego. O resultado final destas quatro forças (ou variáveis) sobre o desemprego dependeria de sua velocidade de crescimento. Dado que a taxa de desemprego nos países industriais ocidentais, ao longo do século XIX e XX, nunca chegou a ultrapassar a taxa de pessoas ocupadas, podemos concluir que as duas forças demandantes de mão de obra foram maiores que as duas forças que aumentavam os trabalhadores ociosos.

\section{$3 O$ caso da indústria de transformação brasileira (1990-2007)}

Verificamos, nos dois capítulos anteriores, que tanto Ricardo como Marx reconheceram a existência do desemprego tecnológico. No entanto, ambos os pensadores enxergaram que um aumento do nível dos investimentos poderia empregar rapidamente os trabalhadores demitidos pelo progresso técnico da nova maquinaria, não ocorrendo, dessa forma, o fenômeno do desemprego tecnológico ${ }^{19}$.

(19) Cardoso e Guedes (1999) analisaram o pensamento de Ricardo e Marx sobre o desemprego tecnológico, mas deixaram escapar a importância dos novos investimentos na absorção dos trabalhadores demitidos pelas máquinas modernas (fato enfatizado por Ricardo e Marx). 
Assim, a principal solução para o problema do desemprego tecnológico é, e sempre foi, um maior crescimento da economia ${ }^{20}$.

O objetivo deste terceiro capítulo é verificar se, após a abertura econômica brasileira (a partir de 1990), ocorreu por algum tempo o fenômeno do desemprego tecnológico no país. Optamos por estudar a indústria de transformação por ser o setor produtivo que passou por um vigoroso processo de reestruturação produtiva no período.

A Tabela 1 apresenta a evolução do emprego formal na indústria de transformação brasileira de dezembro de 1989 até dezembro de 2007. No geral, podemos constatar que ocorreram quatro fases no emprego industrial no período: 1) de janeiro de 1990 a fevereiro de 1994; 2) de março de 1994 a maio de 1995; 3) de junho 1995 a março de 1999; 4) de abril de 1999 a dezembro de 2007.

Na primeira fase (Tabela 1), observamos que o nível de emprego formal na indústria de transformação teve uma queda de 16,2\%, entre janeiro de 1990 e fevereiro de $1994^{21}$. É lógico que essa queda no emprego industrial não se deveu apenas ao avanço tecnológico oriundo da reestruturação produtiva do setor. Quatro fatores principais explicam a queda do emprego industrial: 1) retração do PIB;2) abertura comercial; 3) privatizações de empresas federais; 4) reestruturação produtiva do setor industrial $^{22}$.

(20) Mattoso (1998) constatou que quando o crescimento econômico -foi menor que o crescimento da produtividade industrial, sem redução da jornada de trabalho, o desemprego aumentou na Alemanha, França, Itália, Inglaterra, Estados Unidos, Canadá e Japão. Já Oliveira (1998, p. 13-16) destacou que, nos países desenvolvidos do pós-guerra, “(...) o rápido crescimento logo reabsorvia os trabalhadores eliminados pelo progresso técnico”, mas a partir dos anos 1970, “(...) com a redução das taxas de crescimento e a revolução tecnológica, o desemprego aumentou (...)”. Na mesma linha de raciocínio está Salm (1997, p. 1340), que através de tabelas de desemprego, crescimento da produtividade e taxas de crescimento do PIB nos países desenvolvidos (Alemanha, França, Itália, Reino Unido, Estados Unidos e Japão) demonstrou “(...) que não foi simplesmente o aumento da produtividade a causa do aumento no desemprego dos anos 70 para cá, mas que o desemprego está fortemente associado ao menor crescimento".

(21) Segundo Baltar (1998, p. 138), "O emprego no conjunto da indústria de transformação [na primeira metade dos anos 90] caiu cerca de $15 \%$ e não aumentou com a recuperação da economia e a elevação da produção manufatureira (...) Isso ocorreu, em parte, devido ao aumento de produtividade com mudanças de organização do trabalho, processos e equipamentos, mas também em consequência da terceirização de atividades e da importação de bens intermediários, que permitiram aumentar a produção final, principalmente de bens duráveis de consumo, sem aumentar o emprego da indústria do país".

(22) As variáveis econômicas possuem múltiplas inter-relações. Uma variável influencia outra e viceversa. Por exemplo: o crescimento da economia (PIB) influencia o crescimento da produção industrial que, por sua vez, influencia o crescimento da economia. Por isso, isolar algumas variáveis, buscando identificar as causas de determinado problema, no caso a queda do emprego industrial, é uma aproximação provável, mas não exata. Sobre este tema, Keynes (1985, p. 172) escreveu que “(...) num estudo tão complexo como o da economia, onde não é possível esperar generalizações completamente exatas, [devemos] descobrir os fatores cujas variações determinam principalmente o nosso quaesitum". Mais à frente, Keynes completou o raciocínio: "Os métodos pseudomatemáticos, que dão a figuração simbólica de um sistema de análise econômica (...) têm o grave defeito de supor expressamente a independência rigorosa dos fatores que utilizam, e de perder sua coesão lógica e autoridade quando esta hipótese é rejeitada (...)" (Ibid, p. 206). 
Tabela 1

Índice de emprego formal na indústria de transformação - Brasil - 1989-2007 (Dez./07=100)

\begin{tabular}{|c|c|c|c|c|c|c|c|}
\hline Período & Índice & Período & Índice & Período & Índice & Período & Índice \\
\hline Dez/89 & 97,57 & $\mathrm{jul} / 94$ & 82,72 & $\mathrm{fev} / 99$ & 70,84 & set/03 & 81,68 \\
\hline $\mathrm{Jan} / 90$ & 97,09 & ago/94 & 82,73 & $\mathrm{mar} / 99$ & 70,51 & out $/ 03$ & 81,92 \\
\hline $\mathrm{Fev} / 90$ & 96,59 & set/94 & 83,31 & $\mathrm{abr} / 99$ & 70,86 & nov/03 & 81,73 \\
\hline $\mathrm{Mar} / 90$ & 96,03 & out/94 & 83,83 & maio/99 & 71,36 & $\mathrm{dez} / 03$ & 80,45 \\
\hline $\mathrm{Abr} / 90$ & 94,15 & nov/94 & 83,88 & jun/99 & 71,67 & $\mathrm{jan} / 04$ & 80,99 \\
\hline Maio/90 & 93,24 & $\mathrm{dez} / 94$ & 83,19 & jul/99 & 71,74 & $\mathrm{fev} / 04$ & 81,56 \\
\hline Jun/90 & 93,36 & $\mathrm{jan} / 95$ & 83,15 & ago/99 & 71,87 & $\mathrm{mar} / 04$ & 82,31 \\
\hline $\mathrm{Jul} / 90$ & 93,81 & fev/95 & 83,43 & set/99 & 72,34 & $\mathrm{abr} / 04$ & 83,28 \\
\hline Ago/90 & 94,27 & $\mathrm{mar} / 95$ & 83,59 & out/99 & 72,81 & maio/04 & 84,61 \\
\hline Set $/ 90$ & 94,86 & $\mathrm{abr} / 95$ & 83,90 & nov/99 & 72,82 & jun/04 & 85,32 \\
\hline Out/90 & 94,56 & maio/95 & 84,30 & $\mathrm{dez} / 99$ & 71,79 & $\mathrm{jul} / 04$ & 86,16 \\
\hline Nov/90 & 92,62 & jun/95 & 83,95 & $\mathrm{jan} / 00$ & 71,97 & ago/04 & 87,24 \\
\hline Dez/90 & 89,73 & $\mathrm{jul} / 95$ & 83,24 & fev/00 & 72,31 & set/04 & 88,73 \\
\hline Jan/91 & 88,02 & $\mathrm{ago} / 95$ & 82,25 & $\mathrm{mar} / 00$ & 72,52 & out/04 & 89,51 \\
\hline Fev/91 & 86,87 & set/95 & 81,90 & $\mathrm{abr} / 00$ & 72,98 & nov/04 & 89,63 \\
\hline Mar/91 & 86,44 & out/95 & 81,44 & maio/00 & 73,60 & $\mathrm{dez} / 04$ & 87,97 \\
\hline $\mathrm{Abr} / 91$ & 86,83 & nov/95 & 80,72 & jun/00 & 73,82 & $\mathrm{jan} / 05$ & 88,46 \\
\hline Maio/91 & 87,65 & $\mathrm{dez} / 95$ & 79,47 & $\mathrm{jul} / 00$ & 74,13 & $\mathrm{fev} / 05$ & 88,47 \\
\hline Jun/91 & 88,42 & $\mathrm{jan} / 96$ & 79,08 & ago/00 & 74,45 & $\mathrm{mar} / 05$ & 88,73 \\
\hline $\mathrm{Jul} / 91$ & 89,04 & fev/96 & 78,66 & set $/ 00$ & 75,13 & $\mathrm{abr} / 05$ & 89,91 \\
\hline Ago/91 & 89,56 & $\mathrm{mar} / 96$ & 78,26 & out $/ 00$ & 75,47 & maio/05 & 90,60 \\
\hline Set/91 & 89,96 & abr/96 & 78,41 & nov/00 & 75,58 & jun $/ 05$ & 90,85 \\
\hline Out/91 & 89,27 & maio/96 & 78,87 & $\mathrm{dez} / 00$ & 74,61 & $\mathrm{jul} / 05$ & 90,94 \\
\hline Nov/91 & 87,65 & jun/96 & 79,02 & $\mathrm{jan} / 01$ & 74,97 & ago/05 & 91,21 \\
\hline Dez/91 & 85,75 & jul/96 & 78,98 & $\mathrm{fev} / 01$ & 75,15 & set/05 & 92,42 \\
\hline Jan/92 & 85,04 & ago/96 & 78,88 & $\mathrm{mar} / 01$ & 75,15 & out $/ 05$ & 92,81 \\
\hline $\mathrm{Fev} / 92$ & 84,30 & set/96 & 79,12 & $\mathrm{abr} / 01$ & 75,58 & nov/05 & 92,14 \\
\hline Mar/92 & 83,75 & out/96 & 79,09 & maio/01 & 76,04 & $\mathrm{dez} / 05$ & 90,61 \\
\hline $\mathrm{Abr} / 92$ & 83,38 & nov/96 & 78,70 & jun/01 & 76,18 & $\mathrm{jan} / 06$ & 90,89 \\
\hline Maio/92 & 83,50 & $\mathrm{dez} / 96$ & 77,48 & jul/01 & 76,15 & $\mathrm{fev} / 06$ & 91,23 \\
\hline Jun/92 & 83,41 & $\mathrm{jan} / 97$ & 77,37 & ago/01 & 76,16 & $\mathrm{mar} / 06$ & 91,60 \\
\hline $\mathrm{Jul} / 92$ & 83,17 & $\mathrm{fev} / 97$ & 77,32 & set $/ 01$ & 76,64 & $\mathrm{abr} / 06$ & 92,75 \\
\hline Ago/92 & 83,06 & $\mathrm{mar} / 97$ & 77,30 & out/01 & 77,02 & maio/06 & 93,46 \\
\hline Set/92 & 83,12 & $\mathrm{abr} / 97$ & 77,50 & nov/01 & 77,03 & jun/06 & 93,75 \\
\hline Out/92 & 82,90 & maio/97 & 77,88 & $\mathrm{dez} / 01$ & 76,12 & $\mathrm{jul} / 06$ & 94,06 \\
\hline Nov/92 & 82,55 & jun/97 & 78,01 & $\mathrm{jan} / 02$ & 76,35 & ago/06 & 94,49 \\
\hline Dez/92 & 81,31 & $\mathrm{jul} / 97$ & 77,87 & $\mathrm{fev} / 02$ & 76,47 & set/06 & 95,68 \\
\hline Jan/93 & 81,59 & ago/97 & 77,75 & $\mathrm{mar} / 02$ & 76,83 & out/06 & 96,35 \\
\hline Fev/93 & 81,68 & set/97 & 77,96 & $\mathrm{abr} / 02$ & 77,49 & nov/06 & 95,95 \\
\hline $\mathrm{Mar} / 93$ & 81,91 & out/97 & 77,85 & maio/02 & 77,87 & $\mathrm{dez} / 06$ & 94,27 \\
\hline $\mathrm{Abr} / 93$ & 82,00 & nov/97 & 77,37 & jun/02 & 78,02 & $\mathrm{jan} / 07$ & 94,83 \\
\hline Maio/93 & 82,93 & $\mathrm{dez} / 97$ & 75,92 & $\mathrm{jul} / 02$ & 78,04 & fev/07 & 95,28 \\
\hline Jun/93 & 83,32 & $\mathrm{jan} / 98$ & 75,20 & ago/02 & 78,29 & $\mathrm{mar} / 07$ & 95,87 \\
\hline $\mathrm{Jul} / 93$ & 83,36 & fev/98 & 74,75 & set/02 & 79,39 & $\mathrm{abr} / 07$ & 97,38 \\
\hline Ago/93 & 83,28 & $\mathrm{mar} / 98$ & 74,50 & out $/ 02$ & 79,63 & maio/07 & 98.22 \\
\hline Set/93 & 83,30 & $\mathrm{abr} / 98$ & 74,66 & nov/02 & 79,47 & jun/07 & 98.62 \\
\hline Out/93 & 83,26 & maio/98 & 74,86 & $\mathrm{dez} / 02$ & 78,51 & $\mathrm{jul} / 07$ & 99,05 \\
\hline Nov/93 & 82,93 & jun/98 & 74,85 & $\mathrm{jan} / 03$ & 78,91 & ago/07 & 99,62 \\
\hline Dez/93 & 81,91 & jul/98 & 74,31 & fev/03 & 78,94 & set/07 & 101,24 \\
\hline Jan/94 & 81,93 & ago/98 & 74,25 & $\mathrm{mar} / 03$ & 79,12 & out $/ 07$ & 102,11 \\
\hline $\mathrm{Fev} / 94$ & 81,72 & set/98 & 74,22 & $\mathrm{abr} / 03$ & 79,86 & nov/07 & 102,07 \\
\hline Mar/94 & 81,79 & out/98 & 73,98 & maio/03 & 80,31 & $\mathrm{dez} / 07$ & 100,00 \\
\hline $\mathrm{Abr} / 94$ & 82,01 & nov/98 & 73,31 & jun/03 & 80,43 & & \\
\hline Maio/94 & 82,50 & $\mathrm{dez} / 98$ & 71,58 & $\mathrm{jul} / 03$ & 80,29 & & \\
\hline Jun/94 & 82,78 & $\mathrm{jan} / 99$ & 71,31 & ago/03 & 80,58 & & \\
\hline
\end{tabular}

Fonte: MTE (In: BCB, Tabela 1588, 2008). 
As medidas econômicas recessivas implantadas no Plano Collor, de 15 de março de 1990, que visavam o combate à alta inflação e o processo de impeachment do presidente Fernando Collor de Mello (aberto em setembro de 1992, mas que já causava turbulência política desde outubro de 1991) tiveram efeitos diretos na queda do PIB de 1990 e 1992 e, evidentemente, na redução da produção industrial (Tabela 2). Em 1990, a produção industrial caiu 9,46\% e, em 1992, a queda foi de 4,21\%. Já em 1991, embora houvesse crescimento da economia, este foi insignificante para a indústria de transformação $(0,15 \%)$. Assim, a retração do PIB e, consequentemente, a diminuição da produção industrial, entre 1990 e 1992, explica parte da queda do emprego industrial no período.

Tabela 2

Produto interno bruto (PIB) e produto na indústria de transformação Brasil - Variação real anual - 1989-2007

\begin{tabular}{c|c|r|c|c|c}
\hline \multirow{2}{*}{ Período } & \multicolumn{2}{|c|}{ Variação (\%) } & \multirow{2}{*}{ Período } & \multicolumn{2}{c}{ Variação (\%) } \\
\cline { 2 - 3 } & Brasil & Ind. & & Brasil & Ind. \\
\hline 1989 & 3,16 & 2,88 & 1999 & 0,25 & $-1,86$ \\
\hline 1990 & $-4,35$ & $-9,46$ & 2000 & 4,31 & 5,69 \\
\hline 1991 & 1,03 & 0,15 & 2001 & 1,31 & 0,70 \\
\hline 1992 & $-0,47$ & $-4,21$ & 2002 & 2,66 & 2,44 \\
\hline 1993 & 4,67 & 9,28 & 2003 & 1,15 & 1,85 \\
\hline 1994 & 5,33 & 8,14 & 2004 & 5,71 & 8,47 \\
\hline 1995 & 4,42 & 4,93 & 2005 & 3,16 & 1,25 \\
\hline 1996 & 2,15 & 0,08 & 2006 & 3,75 & 1,98 \\
\hline 1997 & 3,38 & 2,49 & 2007 & 5,42 & 5,06 \\
\hline 1998 & 0,04 & $-4,84$ & & & \\
\hline
\end{tabular}

Fonte: IBGE (In: Ipeadata, 2008).

Já a abertura comercial teve seu início ainda durante o governo Sarney: entre 1986 e 1989, a alíquota legal geral de importações reduziu-se 26,9\% (Tabela 3). Mas foi com a implantação da nova Política Industrial e de Comércio Exterior (PICE), em 26 de junho de 1990, no primeiro ano do governo Collor, que o processo de abertura comercial se intensificou. Além da redução das alíquotas de importação, a PICE eliminou os controles quantitativos de importações e outras barreiras ao comércio exterior (entre elas, a lista negra da Cacex, que proibia a importação de vários produtos). Entre 1989 e 1993, a alíquota média de importação caiu 48,6\%. Com a eliminação das quotas, proibições e a queda das alíquotas, os produtos importados tomaram parte do mercado interno que antes era ocupado pela indústria nacional. Muitas empresas que não se modernizaram ao padrão internacional fecharam suas portas. Desta forma, a abertura comercial do país contribuiu para diminuir a produção interna e o emprego formal na indústria de transformação. 
Tabela 3

Alíquota legal geral de importações

Brasil - média anual (em \%) - 1984-2005

\begin{tabular}{c|c|c|c}
\hline Período & Alíquota & Período & Alíquota \\
\hline 1984 & 22,05 & 1995 & 14,92 \\
\hline 1985 & 20,01 & 1996 & 13,60 \\
\hline 1986 & 30,81 & 1997 & 13,80 \\
\hline 1987 & 27,40 & 1998 & 16,74 \\
\hline 1988 & 26,39 & 1999 & 10,65 \\
\hline 1989 & 22,53 & 2000 & 12,68 \\
\hline 1990 & 18,61 & 2001 & 10,81 \\
\hline 1991 & 15,62 & 2002 & 9,35 \\
\hline 1992 & 13,86 & 2003 & 8,98 \\
\hline 1993 & 11,59 & 2004 & 8,24 \\
\hline 1994 & 12,74 & 2005 & 8,45 \\
\hline
\end{tabular}

Fonte: Ipeadata (2008).

O Programa Nacional de Desestatização do governo Collor teve início em 12 de abril de 1990, com a publicação da Lei n. 8031. O programa de privatização e o seu financiamento ficaram a cargo do BNDES. Entre 1991 e 1992, foram privatizadas 18 empresas estatais dos setores siderúrgico, petroquímico e de fertilizantes. Já entre 1993 e 1994, aconteceram 15 novas privatizações federais nos setores químico e de fertilizantes (Cysne, 1999). As privatizações tiveram papel importante no corte de custos (principalmente os relativos à força de trabalho) e no aumento dos investimentos para obter maior produtividade, na tentativa de adequação ao mercado internacional. Desta forma, as privatizações também contribuíram para a redução do emprego formal industrial, pois as empresas privatizadas trataram de reduzir seu quadro de pessoal, visto que todas as empresas públicas brasileiras eram atrasadas tecnologicamente e, na maioria das vezes, funcionavam como 'cabides' de emprego.

O último fator que impactou a queda do nível de emprego industrial, nesta primeira fase, foi a reestruturação produtiva do parque industrial brasileiro. A reestruturação foi motivada pela abertura comercial (que exigiu investimentos em modernização para competir com as importações) e pela privatização das empresas federais (atrasadas tecnologicamente) ${ }^{23}$. Segundo Mattoso e Pochmann (1998), a

(23) Para Dedecca (1998, p. 181), “A abertura econômica do governo Collor forçou um movimento de racionalização produtiva, que, na ausência de uma política industrial, levou a uma posição defensiva das empresas. Estas adotaram uma posição claramente seletiva, focando sua atividade nos mercados que consideravam ter alguma perspectiva e eliminando capacidade produtiva naqueles avaliados sem qualquer futuro. A redução da capacidade produtiva foi acompanhada por uma certa modernização tecnológica e organizacional, convergente com as tendências internacionais". 
reestruturação produtiva concentrou-se nos grupos de empresas líderes, segmentos dinâmicos e internacionalizados. Tratou-se da implantação de um novo paradigma tecnológico, a chamada revolução microeletrônica, iniciada no mundo desenvolvido na década de 1970, aproveitando com mais racionalidade as matérias-primas e os meios de produção. Este processo teve como foco a maior flexibilização do capital e do trabalho. No entender de Filgueiras (2000, p. 53), reestruturação produtiva são transformações estruturais tanto no âmbito da produção quanto no âmbito do trabalho. Na produção, significa modernização e reorganização da produção; no processo de trabalho, significa a adoção de novos paradigmas de trabalho e organizacional, como automação e flexibilização (terceirização e direitos trabalhistas).

Analisando a Tabela 4, podemos observar que a reestruturação produtiva propiciou um aumento da produtividade na indústria de transformação: em 1993, a produtividade industrial elevou-se em quase $10 \%{ }^{24}$. A falta de dados para os anos de 1990 e 1991 leva-nos a acreditar que o ganho de produtividade da indústria foi bem maior neste período ${ }^{25}$.

Tabela 4

Índice de produtividade da indústria de transformação

1992-2007 (média 1992=100)

\begin{tabular}{c|c|c|c}
\hline Período & $\begin{array}{c}\text { Índice de } \\
\text { Produtividade }\end{array}$ & Período & $\begin{array}{c}\text { Índice de } \\
\text { Produtividade }\end{array}$ \\
\hline 1992 & 100,00 & 2000 & 150,64 \\
\hline 1993 & 109,93 & 2001 & 162,25 \\
\hline 1994 & 99,00 & 2002 & 164,47 \\
\hline 1995 & 109,46 & 2003 & 161,92 \\
\hline 1996 & 121,13 & 2004 & 169,49 \\
\hline 1997 & 134,35 & 2005 & 166,21 \\
\hline 1998 & 144,10 & 2006 & 167,44 \\
\hline 1999 & 150,59 & & \\
\hline
\end{tabular}

Fonte: BCB-DEPEC (Tabela 7354, 2008).

É exatamente na questão da reestruturação produtiva que podemos ou não encontrar o fenômeno do desemprego tecnológico. Para a existência do desem-

(24) O índice de produtividade da indústria de transformação, calculado pelo DEPEC do Banco Central, leva em consideração a produção da indústria de transformação (calculado pelo IBGE) em relação ao número de horas trabalhadas pelo pessoal na produção na indústria de transformação (calculado pelo CNI). O DEPEC optou por não calcular o índice para o ano de 2007 em razão da mudança de metodologia no cálculo das horas trabalhadas feita pela CNI.

(25) Segundo Salm (1997, p. 1354), "Os ganhos de produtividade registrados foram tão elevados - cerca de $8,6 \%$ a.a. na média da indústria de transformação, entre 1990 e 1994 - que certamente merecem estudos mais aprofundados quanto às suas causas". 
prego tecnológico é necessário que os trabalhadores dispensados pela introdução do progresso técnico não encontrem uma nova ocupação no curto prazo. Neste ponto concordamos com Pastore (1998, p. 35), que afirma que para avaliar o efeito final das tecnologias não é suficiente examinar a destruição líquida de emprego, que geralmente ocorre nos locais onde entram as novas tecnologias (conforme apurado na Tabela 1). Mas, sim, é necessário atentar para os efeitos de deslocamento dos trabalhadores e criação de novas atividades e postos de trabalho que estas tecnologias, indiscutivelmente, provocam em outros setores e empresas. É o mesmo raciocínio desenvolvido por Ricardo e Marx: os trabalhadores demitidos pelo progresso da tecnologia podem encontrar novas ocupações rapidamente, não existindo desemprego.

Para avaliar se os trabalhadores demitidos da indústria de transformação encontraram ou não novas ocupações, temos que nos servir de um método aproximado de análise. Tendo por base a taxa de desemprego calculada pelo IBGE, podemos elaborar a seguinte hipótese: se a taxa de desemprego aumentar é porque os demitidos da indústria não encontraram novos empregos; já se a taxa de desemprego não aumentar (ou até mesmo cair) é porque os demitidos encontraram novas ocupações ${ }^{26}$.

Partindo desta hipótese, verificamos pela Tabela 5 que, entre 1989 e 1993, a taxa de desemprego aumentou $58,8 \%$. Diante disso, podemos concluir que a queda do emprego na indústria de transformação não foi compensada pelos demais setores da economia. Não ocorreram "os efeitos de deslocamento dos trabalhadores" para outros setores, na terminologia de Pastore, que compensassem a queda do emprego na indústria de transformação. Assim, sabendo que o progresso tecnológico contido na reestruturação produtiva foi um dos quatro fatores que reduziram o volume do emprego industrial, podemos afirmar, com certa segurança, que, entre 1990 e 1993, o Brasil vivenciou um período de desemprego tecnológico.

(26) Lembramos que esta análise é uma aproximação, pois sabemos que a taxa de desemprego pode aumentar por duas outras razões (além da demissão de trabalhadores): entrada de novos trabalhadores no mercado de trabalho e a volta ao mercado de pessoas que estavam no desalento. Foi benéfica ao nosso método, a redução gradativa da taxa de crescimento da população brasileira na segunda metade do século XX (IBGE, 2008). Caso a população brasileira continuasse a crescer na mesma taxa dos anos 1960, certamente o desemprego da década de 1990 seria muito maior, reduzindo a participação dos demitidos do setor industrial na taxa de desemprego total. $\mathrm{Na}$ década de 1960 , a taxa média anual de crescimento da população era de $2,89 \%$. Na década de 1970 , esta taxa já era bem menor (2,44\%). O decréscimo continuou nas décadas de 1980 (2,14\%) e de 1990 (1,57\%). É oportuno também salientar que, no período de tempo de nosso estudo (1990/2007), não ocorreu nenhuma redução da jornada de trabalho que poderia compensar o aumento da produtividade industrial. 
Desemprego tecnológico: Ricardo, Marx e o caso da indústria de transformação brasileira (1990-2007

Tabela 5

Taxa de desemprego aberto (PME) - 1989-2007

\begin{tabular}{c|r|c}
\hline Anos & Brasil & São Paulo \\
\hline 1989 & 3,35 & 3,44 \\
\hline 1990 & 4,28 & 4,55 \\
\hline 1991 & 4,83 & 5,52 \\
\hline 1992 & 5,66 & 6,51 \\
\hline 1993 & 5,32 & 5,74 \\
\hline 1994 & 5,06 & 5,42 \\
\hline 1995 & 4,65 & 5,17 \\
\hline 1996 & 5,43 & 6,29 \\
\hline 1997 & 5,67 & 6,60 \\
\hline 1998 & 7,60 & 8,59 \\
\hline 1999 & 7,56 & 8,30 \\
\hline 2000 & 7,14 & 7,45 \\
\hline 2001 & 6,24 & 6,39 \\
\hline 2002 & 7,14 & 8,41 \\
\hline 2003 & 12,32 & 14,08 \\
\hline 2004 & 11,48 & 12,63 \\
\hline 2005 & 9,83 & 10,23 \\
\hline 2006 & 9,98 & 10,52 \\
\hline 2007 & 9,29 & 10,11 \\
\hline
\end{tabular}

Fonte: Conjuntura Economia (2008) ${ }^{27}$.

Antes de passar para a segunda fase de nosso estudo, é conveniente observar o que aconteceu com o emprego industrial no estado mais industrializado do país. De acordo com a Tabela 6, entre janeiro de 1990 e fevereiro de 1994, o emprego formal na indústria de transformação do Estado de São Paulo caiu 21,7\%, enquanto no Brasil esta queda foi de 16,2\% (Tabela 1). Nota-se, entretanto, que o emprego industrial em São Paulo continuou caindo nos meses seguintes (até agosto de 1994: queda de 22,8\%). Portanto, o principal centro industrial do país sofreu mais intensamente os efeitos dos quatros fatores que reduziram o emprego industrial no período.

Do mesmo modo que o Brasil, o Estado de São Paulo não conseguiu absorver os demitidos do setor industrial nos outros setores produtivos. A taxa de desocupação aumentou 66,9\% no período de 1989 a 1993.

(27) Até dezembro de 2002, pessoas que haviam procurado trabalho na semana anterior à pesquisa. A partir de janeiro de 2003, pessoas que procuraram trabalho nos últimos 30 dias antes da entrevista.

Economia e Sociedade, Campinas, v. 20, n. 2 (42), p. 299-327, ago. 2011. 
Tabela 6

Índice do pessoal ocupado na indústria de transformação do

Estado de São Paulo - 1989-2007 (média $2006=100$ )

\begin{tabular}{|c|c|c|c|c|c|c|c|}
\hline Período & Índice & Período & Índice & Período & Índice & Período & Índice \\
\hline $\mathrm{dez} / 89$ & 159,92 & jul/94 & 123,89 & fev/99 & 96,11 & set/03 & 86,04 \\
\hline jan/90 & 159,18 & ago/94 & 123,39 & $\mathrm{mar} / 99$ & 95,49 & out/03 & 85,86 \\
\hline fev/90 & 158,29 & set/94 & 123,51 & $\mathrm{abr} / 99$ & 95,36 & nov/03 & 85,94 \\
\hline $\mathrm{mar} / 90$ & 157,84 & out/94 & 124,26 & maio/99 & 95,34 & dez/03 & 85,13 \\
\hline $\mathrm{abr} / 90$ & 154,87 & nov/94 & 124,51 & jun/99 & 95,43 & $\mathrm{jan} / 04$ & 85,88 \\
\hline maio/90 & 152,50 & $\mathrm{dez} / 94$ & 124,51 & jul/99 & 95,41 & fev/04 & 86,36 \\
\hline jun/90 & 151,01 & $\mathrm{jan} / 95$ & 125,13 & ago/99 & 95,43 & $\mathrm{mar} / 04$ & 87,11 \\
\hline jul/90 & 151,46 & fev/95 & 125,75 & set/99 & 95,41 & $\mathrm{abr} / 04$ & 87,65 \\
\hline ago/90 & 151,76 & $\mathrm{mar} / 95$ & 126,37 & out/99 & 95,50 & maio/04 & 89,04 \\
\hline $\mathrm{set} / 90$ & 152,35 & $\mathrm{abr} / 95$ & 126,49 & nov/99 & 95,54 & jun/04 & 89,29 \\
\hline out/90 & 152,05 & maio/95 & 126,24 & dez/99 & 95,38 & jul/04 & 90,06 \\
\hline nov/90 & 150,42 & jun/95 & 125,25 & $\mathrm{jan} / 00$ & 95,59 & $\mathrm{ago} / 04$ & 91,04 \\
\hline $\mathrm{dez} / 90$ & 146,86 & jul/95 & 123,89 & fev/00 & 95,71 & set/04 & 91,78 \\
\hline jan/91 & 143,59 & ago/95 & 120,91 & $\mathrm{mar} / 00$ & 95,82 & out/04 & 92,33 \\
\hline fev/91 & 141,51 & set/95 & 119,17 & $\mathrm{abr} / 00$ & 96,07 & nov/04 & 92,71 \\
\hline $\mathrm{mar} / 91$ & 140,32 & out/95 & 117,93 & maio/00 & 96,39 & $\mathrm{dez} / 04$ & 90,88 \\
\hline $\mathrm{abr} / 91$ & 139,73 & nov/95 & 117,19 & jun/00 & 96,62 & jan/05 & 91,43 \\
\hline maio/91 & 140,47 & $\mathrm{dez} / 95$ & 115,83 & jul $/ 00$ & 96,70 & fev/05 & 91,98 \\
\hline jun/91 & 140,92 & $\mathrm{jan} / 96$ & 114,83 & $\mathrm{ago} / 00$ & 96,88 & $\mathrm{mar} / 05$ & 92,92 \\
\hline jul/91 & 142,10 & fev/96 & 114,09 & set/00 & 97,08 & $\mathrm{abr} / 05$ & 95,09 \\
\hline ago/91 & 143,00 & $\mathrm{mar} / 96$ & 113,47 & out/00 & 97,16 & maio/05 & 95,73 \\
\hline $\mathrm{set} / 91$ & 143,29 & $\mathrm{abr} / 96$ & 113,10 & nov $/ 00$ & 97,42 & jun/05 & 96,14 \\
\hline out/91 & 142,70 & maio/96 & 112,60 & $\mathrm{dez} / 00$ & 97,03 & jul $/ 05$ & 96,38 \\
\hline nov/91 & 140,47 & jun/96 & 112,11 & $\mathrm{jan} / 01$ & 97,25 & ago/05 & 96,19 \\
\hline $\mathrm{dez} / 91$ & 138,99 & jul/96 & 111,73 & fev/01 & 92,92 & set/05 & 95,82 \\
\hline jan/92 & 137,65 & ago/96 & 110,87 & $\mathrm{mar} / 01$ & 92,54 & out/05 & 95,61 \\
\hline $\mathrm{fev} / 92$ & 136,46 & set/96 & 110,49 & $\mathrm{abr} / 01$ & 92,73 & nov $/ 05$ & 95,30 \\
\hline $\mathrm{mar} / 92$ & 135,13 & out/96 & 110,25 & maio/01 & 93,33 & $\mathrm{dez} / 05$ & 93,96 \\
\hline $\mathrm{abr} / 92$ & 134,38 & nov/96 & 109,87 & jun/01 & 92,92 & $\mathrm{jan} / 06$ & 95,01 \\
\hline maio/92 & 133,79 & $\mathrm{dez} / 96$ & 108,88 & jul/01 & 92,48 & fev/06 & 96,15 \\
\hline jun/92 & 132,60 & $\mathrm{jan} / 97$ & 108,76 & ago/01 & 91,69 & $\mathrm{mar} / 06$ & 97,08 \\
\hline jul/92 & 131,56 & fev/97 & 108,63 & set/01 & 91,22 & $\mathrm{abr} / 06$ & 100,37 \\
\hline ago/92 & 130,67 & $\mathrm{mar} / 97$ & 108,63 & out/01 & 90,84 & maio/06 & 101,20 \\
\hline set/92 & 129,93 & $\mathrm{abr} / 97$ & 108,38 & nov/01 & 90,17 & jun/06 & 101,06 \\
\hline out/92 & 129,33 & maio/97 & 108,26 & $\mathrm{dez} / 01$ & 89,66 & jul/06 & 101,61 \\
\hline nov/92 & 128,74 & jun/97 & 108,26 & $\mathrm{jan} / 02$ & 89,20 & ago/06 & 101,57 \\
\hline $\mathrm{dez} / 92$ & 127,70 & jul/97 & 107,64 & fev/02 & 88,95 & set/06 & 101,71 \\
\hline jan/93 & 127,26 & ago/97 & 107,02 & $\mathrm{mar} / 02$ & 88,77 & out/06 & 101,83 \\
\hline fev/93 & 127,40 & set/97 & 106,77 & $\mathrm{abr} / 02$ & 88,91 & nov/06 & 101,94 \\
\hline mar/93 & 127,55 & out/97 & 106,15 & maio/02 & 88,90 & $\mathrm{dez} / 06$ & 100,47 \\
\hline $\mathrm{abr} / 93$ & 127,70 & nov/97 & 105,66 & jun/02 & 88,74 & $\mathrm{jan} / 07$ & 100,38 \\
\hline maio/93 & 128,00 & $\mathrm{dez} / 97$ & 104,66 & jul/02 & 88,42 & fev/07 & 101,02 \\
\hline jun/93 & 128,15 & jan/98 & 103,67 & ago/02 & 88,06 & $\mathrm{mar} / 07$ & 102,05 \\
\hline jul/93 & 128,15 & fev/98 & 103,30 & set/02 & 88,05 & $\mathrm{abr} / 07$ & 104,05 \\
\hline ago/93 & 127,85 & $\mathrm{mar} / 98$ & 102,93 & out/02 & 88,21 & maio/07 & 105,09 \\
\hline set/93 & 127,40 & $\mathrm{abr} / 98$ & 102,80 & nov/02 & 88,00 & jun/07 & 105,24 \\
\hline out/93 & 127,11 & maio/98 & 102,80 & $\mathrm{dez} / 02$ & 86,92 & jul/07 & 105,67 \\
\hline nov/93 & 126,51 & jun/98 & 102,56 & $\mathrm{jan} / 03$ & 86,95 & ago/07 & 105,71 \\
\hline $\mathrm{dez} / 93$ & 125,92 & jul/98 & 102,31 & fev/03 & 86,92 & set/07 & 106,45 \\
\hline jan/94 & 125,62 & ago/98 & 101,69 & $\mathrm{mar} / 03$ & 86,82 & out/07 & 106,86 \\
\hline fev/94 & 125,25 & set/98 & 101,44 & $\mathrm{abr} / 03$ & 86,99 & nov/07 & 107,09 \\
\hline $\mathrm{mar} / 94$ & 124,75 & out/98 & 100,82 & maio/03 & 87,11 & $\mathrm{dez} / 07$ & 105,32 \\
\hline $\mathrm{abr} / 94$ & 124,38 & nov/98 & 99,33 & jun/03 & 86,91 & & \\
\hline maio/94 & 124,13 & $\mathrm{dez} / 98$ & 97,97 & jul/03 & 86,32 & & \\
\hline jun/94 & 124,01 & jan/99 & 96,98 & ago/03 & 86,16 & & \\
\hline
\end{tabular}

Fonte: FIESP - CIESP (In: Ipeadata, 2008). 
Para terminar a análise dessa primeira fase é conveniente um exame mais detalhado sobre o ano de 1993. Mesmo com o aumento da produtividade industrial de $9,9 \%$, com a queda da alíquota de importação (de 13,86\%, em 1992, para $11,59 \%$, em 1993) e do prosseguimento das privatizações federais, o emprego industrial se manteve estável neste ano (Tabela 1), inclusive com uma pequena elevação de 2,5\% (entre dezembro de 1992 e julho de 1993). O que possibilitou que o emprego industrial não se reduzisse nesse ano (e subisse 2,5\% durante alguns meses) foi o crescimento vigoroso da economia (4,67\%), principalmente da indústria de transformação $(9,28 \%$; Tabela 2$)$. Temos, portanto, um bom exemplo de como o crescimento da economia pode evitar uma elevação do desemprego quando outros fatores, entre eles a inovação tecnológica, conspiram para tal.

A segunda fase do emprego industrial, que podemos observar na Tabela 1, ocorreu entre março de 1994 e maio de 1995. Neste pequeno período, houve um crescimento de 3,2\% do emprego. Três fatores explicam, em grande parte, o crescimento do emprego industrial: 1) crescimento da economia; 2) retrocesso na abertura comercial; 3) queda da produtividade industrial.

O bom crescimento da economia brasileira foi motivado, principalmente, pelo sucesso do plano de estabilização de preços, batizado de Plano Real (cuja nova moeda entrou em circulação em julho de 1994). O Plano teve reflexo direto no aumento do poder de compra da população e nos investimentos produtivos. A consequência foi a elevação do PIB industrial (Tabela 2) em 1994 (8,14\%) e 1995 (4,93\%). O crescimento da economia e, consequentemente, da produção industrial foi o principal motivo para o aumento do emprego neste período.

Já o retrocesso da abertura comercial pode ser visualizado na Tabela 3. Nota-se que a alíquota geral de importações aumentou de 11,59\% em 1993 para 12,74\% em 1994 e 14,92\% em 1995, rompendo, desta maneira, com o ciclo de abertura comercial que vinha acontecendo desde 1987. Esta elevação da alíquota sobre importações, ao garantir uma maior proteção à indústria nacional no mercado interno, contribuiu para aumentar a produção industrial e, em razão disso, o emprego no setor.

O terceiro fator que contribuiu para o aumento do emprego foi a queda de 9,9\% no índice de produtividade industrial, em 1994 (Tabela 4). Os resultados destes três fatores não ficaram somente no aumento do emprego industrial, mas também se refletiu nos outros setores da economia. A taxa de desemprego da economia brasileira, entre 1993 e 1995, teve uma queda de 12,6\% (Tabela 5).

No Estado de São Paulo, o crescimento do emprego industrial começou tardiamente, em setembro de 1994, e terminou antes do país, em abril de 1995 . O saldo foi positivo em $2,5 \%$ (Tabela 6 ), inferior ao saldo do país $(3,2 \%)$. 
A terceira fase do emprego na indústria de transformação brasileira, entre junho de 1995 e março de 1999, apresentou forte declínio no emprego: 16,4\% (Tabela 1). Três fatores principais explicam esta queda: 1) baixo crescimento econômico; 2) sobrevalorização cambial; 3) continuidade do processo de reestruturação produtiva.

O baixo crescimento econômico deveu-se, principalmente, à política de juros altos do Banco Central, às crises financeiras internacionais (México, 1995; Asiática, 1997; Russa, 1998) e à sobrevalorização da moeda nacional em relação ao dólar (favorecendo o aumento das importações e desfavorecendo o crescimento das exportações). Assim, nos três anos cheios deste período (1996, 1997 e 1998), a taxa média de crescimento do PIB foi de apenas $1,9 \%$ ao ano. No setor industrial, o desastre foi bem maior: o PIB trienal caiu 2,4\% (Tabela 2). Num caso deste, em que a produção industrial tem redução, o emprego no setor é a primeira vítima do processo.

Quanto à sobrevalorização cambial, temos que considerar a seguinte questão. De forma geral, a proteção da indústria nacional contra a concorrência internacional se dá por três meios: a) impostos de importação elevados; b) proibição e cotas para importação; c) moeda nacional desvalorizada em relação ao dólar. As proibições e cotas foram extintas em 1990, mas as tarifas de importação (Tabela 3) não tiveram grande redução no período (inclusive aumentando em 1998). Assim, o que vitimou a indústria nacional foi a valorização do real em relação ao dólar. Dependendo da metodologia empregada, a moeda nacional valorizou-se entre $20 \%$ e $30 \%$, aumentando a competição no mercado interno e desfavorecendo as exportações industriais. Desta forma, a sobrevalorização cambial favoreceu a queda da produção industrial e a redução do emprego no setor.

Já a reestruturação produtiva continuou sua expansão neste período (Tabela 4). O índice de produtividade da indústria cresceu 45,6\%, entre 1994 e 1998. Para sabermos se essa reestruturação produtiva na indústria de transformação causou o fenômeno do desemprego tecnológico, temos que avaliar o que aconteceu com o emprego como um todo.

Analisando a taxa de desemprego do Brasil (Tabela 5), constatamos que a mesma cresceu 63,4\% nos anos de 1996, 1997 e 1998. Como a queda do emprego na indústria de transformação não foi compensada nos demais setores da economia, podemos afirmar que, entre junho de 1995 e março de 1999, o Brasil passou por uma nova fase de desemprego tecnológico, pois a reestruturação 
produtiva somada ao baixo crescimento da economia e a valorização cambial foram os principais motivos da queda do emprego industrial ${ }^{28}$.

Em relação ao Estado de São Paulo, o resultado não foi diferente: queda do emprego industrial de 24,7\% (Tabela 6) no período entre maio de 1995 e maio de 1999. Para o mesmo período no Brasil (junho de 1995 a março de 1999), o declínio do emprego no Estado de São Paulo também foi maior: 23,7\%, contra $16,4 \%$ no Brasil. Deste modo, constatamos, mais uma vez, que os efeitos da reestruturação produtiva para o emprego foram mais intensos em São Paulo do que no resto do país.

Podemos, ainda, analisar a queda do emprego industrial através de um período mais longo, excluindo o crescimento de 1994 e 1995. Neste caso, o intervalo de análise vai de janeiro de 1990 a dezembro de 1998 (anos fechados para facilitar as comparações). No Brasil, a queda do emprego industrial foi de 26,6\%, e em São Paulo de 38,7\%. A produção industrial brasileira, por outro lado, cresceu 5,1\% no mesmo período (Tabela 2), enquanto a produtividade aumentou 44,1\% (entre 1992 e 1998; Tabela 4). Já a taxa de desemprego no Brasil cresceu $126,9 \%$ e a de São Paulo ainda mais, 149,7\% (Tabela 5). Assim, sabendo que a reestruturação produtiva foi um dos principais fatores que reduziram o emprego industrial, podemos afirmar, com certa segurança, que o Brasil assistiu, durante grande parte da década de 1990, à existência do desemprego tecnológico.

Por fim, chegamos à quarta fase do emprego na indústria de transformação. Este período se estende de abril de 1999 até o final de nossa análise (ou seja, dezembro de 2007). Observando a Tabela 1, verificamos que, nesta fase, o emprego industrial aumentou $41,8 \%$. Três fatores explicam o forte crescimento do emprego: 1) maior crescimento da economia; 2) desvalorização cambial de 1999; 3) menor ritmo da reestruturação produtiva.

Entre os anos de 2000 a 2007 (Tabela 2), o crescimento médio anual do PIB, de 3,9\%, foi bem superior ao crescimento do período 1996/1998 $(1,9 \%)$. Entretanto, este crescimento médio encobre anos ruins como de 2001 (apagão elétrico), 2002 (instabilidade política provocada pela possibilidade de eleição de

(28) Segundo Antunes (1999, p. 34), as transformações produtivas, que aconteceram em maior ou menor escala, afetaram diretamente o operário industrial tradicional, colocando-o na lista de desempregados. Afirma 0 autor que as tendências e os dados evidenciam uma redução do proletariado fabril, industrial e manual, decorrente da automação, do quadro recessivo do país, da robótica ou da microeletrônica: “(...) o mais brutal resultado dessas transformações é a expansão, sem precedentes na era moderna, do desemprego estrutural” (Ibid, p. 41). Prado (1999, p. 20) insere-se nesta mesma linha de raciocínio. "Nessa circunstância, a reestruturação produtiva é acompanhada por desemprego tecnológico, pois o aumento da produtividade, somado ao da PEA, é muito superior ao crescimento do PIB”. Segundo Prado, após a implantação do Plano Real, o Brasil conviveu tanto com o desemprego conjuntural (causado pelo baixo crescimento) como pelo desemprego estrutural (causado pelo progresso tecnológico). Para o autor, a redução da jornada de trabalho seria a saída histórica para as situações em que a produtividade cresce de forma sustentada. 
um candidato de esquerda à Presidência da República) e 2003 (juros altos e superávit primário expressivo). A produção industrial seguiu os passos do crescimento do PIB: elevou-se, em média, 3,8\% ao ano (2000/2007). O crescimento da economia e, consequentemente, da produção industrial explica parte da elevação do emprego industrial no período.

Também a desvalorização cambial de janeiro de 1999 contribuiu para o aumento do produto e do emprego industrial. Como já foi dito, uma taxa de câmbio desvalorizada acaba servindo de proteção à indústria nacional no mercado interno e favorecendo as exportações do setor. Entre dezembro de 1998 e dezembro de 2001, a taxa de câmbio nominal comercial (média mensal de venda) desvalorizou-se $96 \%$ (de $\mathrm{R} \$ 1,2054$ para $\mathrm{R} \$ 2,3627$ por dólar). A desvalorização cambial também foi suficiente para proteger a indústria nacional da queda da alíquota geral de importações (que ocorreu de 1999 em diante; Tabela 3$)^{29}$.

O crescimento da produtividade industrial, por sua vez, não é mais tão intenso como na década de 1990. Entre 1992 e 1999, a produtividade industrial cresceu 50,6\%, enquanto, no período de 2000 a 2006, o crescimento foi de apenas $11,2 \%$. Percebe-se claramente um esgotamento do processo de reestruturação produtiva, evidenciando que o parque industrial brasileiro já absorveu boa parte das inovações da Terceira Revolução Industrial. Assim, qualquer aumento da produção acontece mediante a expansão da capacidade produtiva e a contratação de novos trabalhadores ${ }^{30}$.

Como ocorreu na segunda fase, o crescimento do emprego não se restringiu apenas ao setor industrial. Entre 1999 e 2002, a taxa de desemprego no Brasil caiu 6,6\%. Mudanças na metodologia da pesquisa de emprego do IBGE, em 2002, impedem que se faça uma análise para os outros anos. Porém, trabalhando com os números de 2003 a 2007, observamos outra forte redução de $24,6 \%$ no desemprego brasileiro neste período (Tabela 5).

(29) No final de 2002, o medo provocado pela eleição presidencial, elevou drasticamente a taxa de câmbio nominal, chegando à média mensal de $\mathrm{R} \$ 3,8059$, em outubro de 2002. Desde este pico, a taxa de câmbio vem se valorizando mensalmente. Em dezembro de 2007, a taxa média ficou em R\$1,7860. Este novo período de valorização já vem prejudicando vários segmentos industriais importantes, o que certamente impediu um maior crescimento da produção e do emprego industrial no período.

(30) Neste período, o que aconteceu no setor industrial, e nos demais setores, foram atualizações e upgrades de softwares e maquinários. Um exemplo disto foi a introdução dos computadores que substituíram as máquinas de escrever e, posteriormente, estes novos computadores não foram substituídos por outros sistemas produtivos, mas sim através de atualizações dos softwares e upgrades internos. Em entrevista à Folha de S.Paulo, o professor David Kupfer (do Instituto de Economia da UFRJ) afirmou em abril de 2005: "Tudo leva a crer que qualquer crescimento econômico que resultar em aumento de produção deve elevar proporcionalmente também o emprego. Muitos setores - papel e celulose, petroquímica e siderúrgico - já completaram a fase mais intensa de modernização tecnológica" (Folha de S. Paulo, 10 abr. 2005, p. B6). 
Em São Paulo, o caso foi um pouco diferente do Brasil. Entre junho de 1999 e novembro de 2000, o emprego industrial cresceu 2,2\%. Mas, a partir de dezembro de 2000 até dezembro de 2003, houve uma queda do emprego em $12,6 \%$. A nova fase de crescimento teve início em janeiro de 2004 e continua até dezembro de 2007: neste período, o emprego cresceu 23,7\% no Estado de São Paulo.

Assim, nesta quarta fase, ficou claramente demonstrado que quando o crescimento da economia é mais intenso, ele consegue absorver os demitidos pelo progresso técnico bem como os novos trabalhadores que ingressam no mercado de trabalho, evitando o aumento do desemprego e até mesmo reduzindo-o.

Em termos absolutos, o volume do emprego na indústria de transformação já voltou, em 2007, ao mesmo patamar de 1990, quando teve início o processo de abertura da economia brasileira (Tabela 1), embora o mesmo não tenha ocorrido com o Estado de São Paulo (Tabela 6). Outros motivos, como o deslocamento de fábricas para outros estados brasileiros, explicam esse fato.

\section{Conclusão}

David Ricardo e Karl Marx entenderam que a nova maquinaria, dotada de avanços tecnológicos, causava, de início, uma demissão de trabalhadores. A própria história do capitalismo inglês ilustrava momentos em que os trabalhadores demitidos pela introdução da máquina moderna não encontravam novas ocupações, passando por momentos de grande penúria e pobreza. Num desses momentos, ocorreu o movimento luddita da década de 1810 . Tratou-se de um caso claro de desemprego tecnológico.

Entretanto, os dois pensadores compreenderam que novos investimentos (ou, simplesmente, o crescimento da economia) poderiam absorver os trabalhadores demitidos pela nova maquinaria, não ocorrendo o fenômeno do desemprego tecnológico. Tudo dependia da velocidade de avanço da técnica e do crescimento da economia, associado à velocidade do crescimento da população e da redução da jornada de trabalho. $\mathrm{O}$ avanço da tecnologia (que reduzia o emprego) poderia ser compensado pela redução da jornada de trabalho ou pelo crescimento da economia (que aumentavam o emprego). $\mathrm{O}$ crescimento da população (que aumentava a oferta de trabalho e tenderia a elevar o número de desempregados) poderia ser compensado também pelo crescimento da economia e pela redução da jornada de trabalho.

Como ficou demonstrado neste estudo, o Brasil conviveu com o fenômeno do desemprego tecnológico durante a maior parte da década de 1990. Demonstrou também que, quando o crescimento econômico é mais intenso (2000 a 2007), o avanço tecnológico não causa desemprego. 
No entanto, não podemos jogar nas costas do crescimento econômico toda a responsabilidade de absorver os novos trabalhadores bem como os demitidos pelo progresso técnico. A queda da taxa de natalidade ocorrida no Brasil (bem como em vários países do mundo) contribuiu para que o crescimento da economia, nestes anos iniciais do século XXI, reduzisse a taxa de desemprego no país, mesmo com o aumento da produtividade do trabalho. Porém, as novas questões ambientais (como o aquecimento global) vêm impondo limites ao crescimento econômico a qualquer custo. Assim, já está mais do que na hora de o Brasil reduzir a sua jornada de trabalho, ajudando o crescimento na sua tarefa de gerar emprego.

\section{Referências bibliográficas}

ANTUNES, Ricardo. Adeus ao trabalho? Ensaios sobre as metamorfoses e a centralidade do mundo do trabalho. São Paulo: Cortez, 1999.

BALTAR, Paulo. Crise contemporânea e mercado de trabalho no Brasil. In: OLIVEIRA, Marco Antonio (Org.). Economia \& Trabalho: textos básicos. Campinas: Unicamp/IE, 1998.

BANCO CENTRAL DO BRASIL - BCB. Sistema Gerenciador de Séries Temporais. Disponível em: http://www.bcb.gov.br. Acesso em: 9 maio 2008.

BARNES, H. E. Historia de la economía del mundo occidental, hasta principios de la segunda guerra mundial. México: Unión Tipográfica, 1955.

CARDOSO, Sidnéia Reis; GUEDES, Cezar. Emprego e inovações tecnológicas no pensamento econômico. In: DIEESE (Org.). Emprego e desenvolvimento tecnológico: artigos dos pesquisadores. São Paulo: DIEESE; Campinas: CESIT, 1999.

CONJUNTURA ECONÔMICA. Taxa de desemprego aberto. Rio de Janeiro, v. 62, mar. 2008.

CYSNE, Rubens Penha. Aspectos macro e microeconômicos das reformas brasileiras. Rio de Janeiro: Fundação Getúlio Vargas, mar. 1999. Disponível em: http://epge.fgv.br/portal/pesquisa/producao/5326.html. Acesso em: 25 jul. 2006.

DEDECCA, Cláudio Salvadori. Reestruturação produtiva e tendências do emprego. In: OLIVEIRA, Marco Antonio (Org.). Economia \& Trabalho: textos básicos. Campinas: Unicamp/IE, 1998.

DENIS, Henri. História do pensamento econômico. Lisboa: Livros Horizonte, 1978.

FILGUEIRAS, Luiz. História do Plano Real: fundamentos, impactos e contradições. São Paulo: Boitempo, 2000.

HOBSBAWN, Eric. Trabalhadores: estudo sobre a história do operário. Rio de Janeiro: Paz e Terra, 1981.

INSTITUTO BRASILEIRO DE GEOGRAFIA E ESTATÍSTICA - IBGE. Disponível em: http://www.ibge.gov.br. Acesso em: 15 maio 2008. 
IPEADATA. Base de dados: macroeconomia. Disponível em: http://www.ipeadata.gov.br. Acesso em: 15 maio 2008.

KEYNES, John Maynard. A teoria geral do emprego, do juro e da moeda. São Paulo: Nova Cultural, 1985.

Perspectivas econômicas para os nossos netos. In: DE MASI, Domenico. Desenvolvimento sem trabalho. São Paulo: Ed. Esfera, 1999.

MARX, Karl. O Capital: crítica da economia política. São Paulo: Abril Cultural, 1984.

MATTOSO, Jorge. Transformações econômicas recentes e mudanças no mundo do trabalho. In: OLIVEIRA, Marco Antonio (Org.). Economia \& Trabalho: textos básicos. Campinas: Unicamp/IE, 1998.

; POCHMANN, Márcio. Mudanças estruturais e trabalho no Brasil dos anos 90. Economia e Sociedade, Campinas, n. 10, jun. 1998.

OLIVEIRA, Carlos Afonso Barbosa. Industrialização, desenvolvimento e trabalho no pósguerra. In: OLIVEIRA, Marco Antonio (Org.). Economia \& Trabalho: textos básicos. Campinas: Unicamp/IE, 1998.

PADRO, Antonio. Globalização e desemprego nos anos 90. In: DIEESE (Org.). Emprego e desenvolvimento tecnológico: artigos dos pesquisadores. São Paulo: DIEESE; Campinas: CESIT, 1999.

PASTORE, José. O desemprego tem cura? São Paulo: Makron Books, 1998.

RICARDO, David. Essay on the influence of a low price of corn on the profits of stock. In: RICARDO, David. Works and correspondence. Ed. Piero Sraffa. Cambridge University Press, 1965. v. IV.

1982.

. Princípios de economia política e tributação. São Paulo: Abril Cultural, Cultural, 1983

Notas aos princípios de economia política de Malthus. São Paulo: Abril

SALM, Cláudio. Tendências do mercado de trabalho. In: ENCONTRO NACIONAL DE ESTUDOS DO TRABALHO, 4, São Paulo, 1995. Anais... Rio de Janeiro: Associação Brasileira de Estudos do Trabalho - ABET, 1997.

SCHILLING, Voltaire. O ludismo: a rebelião contra o futuro. Disponível em: http://educaterra.terrra.com.br/voltaire/artigos/ludismo.htm. Acesso em: 25 abr. 2008.

SCHUMPETER, Josef. Dez grandes economistas. Rio de Janeiro: Civilização Brasileira, 1958.

SMILES, Samuel. Industrial biography: iron workers and tool makers. Whitefish (Montana): Kessinger Publishing, 2004.

SRAFFA, Piero. Introdução. In: RICARDO, David. Princípios de economia política e tributação. São Paulo: Abril Cultural, 1982.

THOMPSON, E. P. A formação da classe operária inglesa. Rio de Janeiro: Paz e Terra, 1987. 